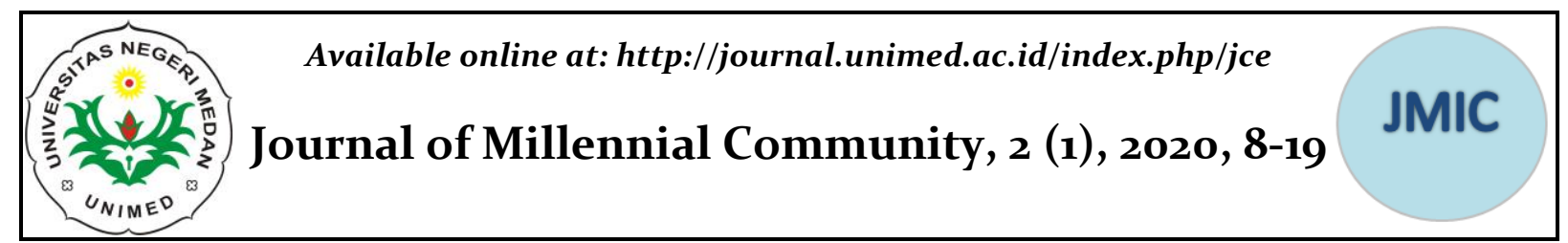

\title{
Pemberdayaan Ibu-ibu Kelompok Emping Desa Kalirejo Melalui In House Training and Workshop
}

\author{
Khairun Nisa ${ }^{1}$, Iis Prasetyo ${ }^{2}$ \\ ${ }^{12}$ Pendidikan Non Formal, Pascasarjana Universitas Negeri Yogyakarta \\ Email: khairunnisa.2018@student.uny.ac.id
}

\begin{abstract}
Abstrak
Penelitian ini bertujuan untuk mendeskripsikan pelaksanaan, hasil, dan faktor keberhasilan program pemberdayaan ibu-ibu kelompok emping Desa Kalirejo, Kecamatan Kokap, Kabupaten Kulon Progo. Jenis penelitian ini adalah penelitian kualitatif dengan metode deskriptif. Hasil penelitian menunjukkan (1) Pemberdayaan dapat dilakukan melalui kegiatan pelatihan yang disesuaikan dengan kebutuhan sasaran program. Pemberdayaan ibu-ibu kelompok emping dilakukan dengan pelatihan mengembangkan produksi usaha olahan emping dengan metode In House Training and Workshop. (2) Hasil pelatihan menunjukkan adanya peningkatan pengetahuan dan keterampilan ibu-ibu kelompok emping dalam membuat, mengemas, dan memasarkan hasil inovasi olahan pangan berbahan dasar emping. Dibuktikan dengan menghasilkan 3 varian rasa keripik emping (jagung manis, barbeque, balado), emping pedas manis dan cookies emping, dan produk sudah memiliki label sendiri serta pemasaran yang meningkat. (3) Faktor keberhasilan proram pelatihan meliputi perencanaan program yang matang, motivasi ibu-ibu kelompok emping yang tinggi dalam belajar, narasumber yang berkompeten, ketepatan materi dan penggunaan strategi pelatihan yang tepat serta sarana dan prasarana yang memadai.
\end{abstract}

Kata Kunci: Pemberdayaan, Ibu-ibu Kelompok Emping, In House Training and Workshop

\section{Empowering the Women Group of Emping Chips in Kalirejo Village through In House Training and Workshop}

\begin{abstract}
This study aims to describe the implementation, results, and success factors of the empowerment program of women group of emping chips in Kalirejo Village, Kokap Subdistrict, Kulon Progo Regency. The type of research is qualitative research with descriptive method. The results show (1) Empowerment can be performed through training activities tailored to the needs of the program targets. Empowering women group of emping chips is conducted by training to develop the processed emping business production using In House Training and Workshop method. (2) The results of the training show that there is an increase in the knowledge and skills of women group in making, packaging, and marketing the emping-based food processing innovations. It is shown by the production of 3 variants of emping chips (sweet corn, barbecue, balado), sweetspicy chips and cookies chips, and the products already have label and it increases marketing. (3) Success factors of the training program include meticulous program planning, high motivation of women group of emping chips to learn, competent resource persons, accuracy of the materials and the use of appropriate training strategies and adequate facilities and infrastructure.
\end{abstract}

Keywords: Empowerment, Women Group of Emping Chips, In House Training and Workshop

\section{PENDAHULUAN}

Pemberdayaan adalah upaya untuk memberikan daya (empowerment) atau penguatan (strengthening) kepada masyarakat. Pemberdayaan dapat juga diartikan sebagai kemampuan individu yang 
bersenyawa atau berhubungan dengan masyarakat dalam membangun keberdayaan masyarakat yang bersangkutan sehingga bertujuan untuk menemukan alternatifalternatif baru dalam pembangunan masyarakat (Mardikanto, 2014) Pemberdayaan juga bisa diartikan sebagai suatu proses untuk memfasilitasi dan mendorong masyarakat agar mampu menempatkan diri secara proporsional dan menjadi pelaku utama dalam memanfaatkan lingkungan staretigsnya untuk mencapai suatu keberlanjutan dalam jangka panjang, melalui pengembangan kemampuan masyarakat, perubahan perilaku masyarakat, dan pengorganisasian masyarakat. Gagasan pembangunan yang mengumatakan pemberdayaan masyarakat perlu untuk dipahami sebagai suatu proses transformasi dalam hubungan sosial, eknomi, budaya dan politik masyarakat.

Upaya pemberdayaan masyarakat semakin menjadi kebutuhan, dalam setiap upaya pembangunan dalam rangka peningkatan taraf hidupnya dan merupakan usaha untuk membentuk kemandirian dalam diri masyarakat desa. Pada tahap selanjutnya segala permasalahan yang ada di sekitar masyarakat desa dapat diselesaikan dan diatasi oleh masyarakat desa itu sendiri. Salah satu yang menjadi permasalahan umum dalam setiap masyarakat desa yaitu kemiskinan dan pemenuhan kebutuhan pangan dalam rumah tangga (Sri Mandayani, Rosdiana., 2019)

Ibu-ibu kelompok emping melinjo di Dusun Sengir Desa Kalirejo, Kecamatan Kokap, Kabupaten Kulon Progo adalah sebuah komunitas desa binaan pascasarajana Universitas Negeri Yogyakarta dan organisasi Keluarga Mahasiswa Pascasarajana UNY. Keterbatasan biaya, alat dan pengetahuan membuat ibu-ibu kelompok emping tidak bisa mengembangkan usaha emping mereka, ditambah kondisi emping yang musiman membuat usaha emping ibu-ibu terhenti. Ibu-ibu kelompok emping biasanya menjual produk mereka dalam bentuk mentah, harga emping yang ketika dijual mentah cukup murah, sehingga menuntut ibu-ibu kelompok emping harus dapat berinovasi untuk kelanjutan usaha emping mereka.
Oleh sebab itu, KMP dan pihak pascasarajana UNY mengadakan pelatihan dan pendampingan untuk ibu-ibu kelompok emping Desa Kalirejo agar dapat berinovasi dengan hasil emping mereka.

Emping adalah sejenis camilan atau makanan ringan berupa keripik yang terbuat dari biji melinjo atau belinjo (Gnetum gnemon). Emping yang tersedia di pasaran biasanya memiliki variasi rasa, seperti original, asin dan manis tergantung dari penambahan garam atau karamel gula. Emping biasanya juga dijual dalam bentuk mentah di pasaran. Diversifikasi atau penganekaragaman. Pembuatan emping melinjo diawali dengan menyangrai melinjo, kemudian dikupas dan ditipiskan dengan sejenis palu dari batu. Makanan ini banyak dihasilkan oleh pengusaha kecil. Emping mempunyai siklus naik turun harga yang selalu sama, ini berarti kita dapat dengan mudah memprediksi keuntungan kita. Namun, seiring perkembangan zaman, jika tidak pandai dalam melihat peluang pasar dan inovasi produk maka usaha kita akan ketinggalan. Oleh karena itu, diperlukan adanya inovasi agar usaha tetap berjalan dengan lancar.

In House Training and Workshop menurut Basri dan Rusdiana (Ayuningtyas et al., 2017) adalah program pelatihan yang diselenggarakan di tempat peserta pelatihan (masyarakat) dengan mengoptimalkan potensi-potensi yang ada di masyarakat, menggunkan peralatan kerja dengan materi yang relevan dan permasalahan yang sedang dihadapi masyarakat, sehingga diharapkan peserta pelatihan dapat lebih mudah menyerap dan mengaplikasikan materi untuk menyelesaikan dan mengatasi permasalahan yang dialami dan mampu secara langsung meningkatkan kualitas kinerjanya. Berdasarkan pendapat tersebut dapat disimpulkan bahwa in house training and workshop merupakan program yang diselenggarakan menggunakan peralatan dan materi yang relevan dengan permasalahan yang sedang dihadapi masyarakat, Tujuannya adalah untuk mengembangkan pengetahuan dan keterampilan masyarakat. 
Diversifikasi atau penganekaragaman adalah suatu cara untuk mengadakan lebih dari satu jenis barang/komoditi yang dikonsumsi. Di bidang pangan, diversifikasi memiliki dua makna, yaitu diversifikasi tanaman pangan dan diversifikasi konsumsi pangan. Kedua bentuk diversifikasi tersebut masih berkaitan dengan upaya untuk mencapai ketahanan pangan. Apabila diversifikasi tanaman pangan berkaitan dengan teknis pengaturan polaber cocok tanam, maka diversifikasi konsumsi pangan akan mengatur atau mengelola pola konsumsi masyarakat dalam rangka mencukupi kebutuhan pangan. Karsyno, et al (Kasryno et al., 1993) memandang diversifikasi pangan sebagai upaya yang sangat erat kaitannya dengan peningkatan kualitas sumber daya manusia, pembangunan pertanian di bidang pangan dan perbaikan gizi masyarakat, yang mencakup aspek produksi, konsumsi, pemasaran, dan distribusi.

Teknik pengemasan produk/packaging menjadi salah satu unsur penting dalam suatu produk. Menurut Kotler \& Keller (Nofriyanto et al., 2019) pengemasan adalah kegiatan merancang dan memproduksi wadah atau bungkus sebagai sebuah produk. Pengemasan disebut juga pembungkusan, pewadahan atau pengepakan. Pengemasan memegang peranan penting dalam pengawetan dan mempertahankan mutu suatu produk makanan. Makanan yang diberi wadah atau pembungkus akan tercegah dari kerusakan, pencemaran (debu) serta gangguan fisik (gesekan, benturan, getaran). Disamping itu pengemasan berfungsi untuk menempatkan suatu hasil pengolahan atau produk industri agar mempunyai bentuk-bentuk yang memudahkan dalam penyimpanan, pengangkutan dan distribusi. Fungsi kemasan secara mendasar adalah untuk mewadahi dan melindungi produk dari kerusakan-kerusakan. Hasil ini sesuai dengan pendapat Simamora (dalam Sagita \& Sari, 2019), fungsi kemasan yaitu 1) Fungsi protektif dan 2) fungsipromosional. Fungsi protektif dimaksudkan sebagai upaya untuk menghindari berbagai kemungkinan kerusakan produk, baik karena iklim, prasarana transportasi, distribusi, dan lainnya. Sehingga dengan protektif ini para konsumen tidak perlu menanggung resiko barang rusak. Fungsi promosional yaitu menentukan kemasan agar yang baik secara warna, ukuran, dan penampilan untuk memiliki daya tarik tersendiri bagi pembeli untuk membeli produk tersebut.

Disverifikasi olahan pangan dan pengemasan produk merupakan bentuk usaha peningkatan omset penjualan bahan olahan pangan yang memiliki indikator berupa meingkatnya keterampilan dan omset hasil penjualan suatu produk oalahan pangan. Keberhasilan yang dimaksud bukan hanya keberhasilan dalam jangka pendek, melainkan dalam jangka panjang berupa keberlanjutan usaha produk olahan pangan berbahan dasar emping.

Hasil observasi awal yang dilakukan menunjukkan bahwa kemampuan kelompok ibu-ibu emping di Desa Kalirejo dalam mengembangkan produk, mengemas, dan memasarkan produk olahan emping awal masih tergolong rendah. Secara teoritik, hal ini dijelaskan berdampak pada hasil penjualan produk pangan yang rendah, proses produksi yang terancam stagnan, dan secara umum akan berpengaruh terhadap tingkat kesejahteraan warga Desa Kalirejo, Kecamatan Kokap. Salah satu cara paling efektif untuk mengatasi permasalahan tersebut adalah dengan mengadakan pelatihan kepada kelompok ibu-ibu emping Desa Kalirejo untuk mengembangkan jenisjenis olahan emping dengan membuat keripik emping berbagai rasa dan pengemasan yang kreatif dan menarik, dan pemasaran. sehingga dapat meningkatkan tingkat penjualan dan omzet penjualan hasil olahan bahan pangan emping yang secara tidak langsung dapat meningkatkan kesejahteraan kelompok ibu-ibu emping Desa Kalirejo.

Kegiatan pemberdayaan ibu-ibu yang tergabung dalam kelompok emping di Dusun sengir, Desa Kalirejo, kecamatan Kokap, Kabupaten Kulon Progo dilakukan melalui program pelatihan membuat inovasi olahan emping. Dusun Sengir memiliki 124 kepala keluarga, yang mayoritas penduduknya bermata pencaharian sebagai 
petani. Potensi alam yang disediakan Desa Kalirejo antara lain bamboo, kayu. melinjo dan rempah-rempah seperti lengkuas, jahe, kunyit dan sebagainya. Potensi alam ini kurang dimanfaatkan dengan baik dan kreatif oleh masyarakat desa setempat dikarenakan pengetahuan dan keterampilan yang kurang.

Potensi alam yang melimpah, terutama melinjo yang ada di Dusun Sengir, Desa Kalirejo diolah oleh masyarakat menjadi emping yang dijual dalam bentuk mentah. Belum adanya kegiatan pelatihan untuk mengolah emping menjadi sesuatu yang bernilai jual tinggi yang dapat meningkatkan ekonomi masyarakat menjadi perlu dilakukan pemberdayaan perempuan di Desa Kalirejo dalam bentuk pelatihan inovasi pengolahan makanan berbahan dasar emping.

Dengan demikian, perlu adanya penelitian yang dapat mendeskripsikan bagaimana pelaksanaan program pemberdayaan tersebut dengan menjelaskan kegiatan-kegiatan yang dilakukan secara rinci. Harapannya adalah hasil dari penelitian mampu dijadikan sebuah acuan bagi lembaga lain dalam menyusun program pemberdayaan khususnya bagi kalangan perempuan (ibu-ibu). Berangkat dari alasan tersebut, maka peneliti tertarik untuk mengangkat judul penelitian mengenai pemberdayaan ibu-ibu kelompok emping Desa Kalirejo melalui in house training and workshop.

\section{METODE}

Jenis Penelitian ini adalah penelitian kualitatif dengan metode deskriptif. Penelitian ini dilakukan di Dusun Sengir, Desa Kalirejo, Kabupaten Kulon Progo, Daerah Istimewa Yogyakarta. Lokasi pelatihan program pemberdayaan tersebut berada di balai kegiatan masyarakat Dusun Sengir. Proses pelatihan dilaksanakan dua minggu sekali dan disesuaikan dengan waktu luang peserta pelatihan. Kegiatan ini dilakukan dari mulai bulan AgustusNovember 2019.

Sasaran dalam program pelatihan inovasi olahan emping dengan metode in house training and workshop adalah ibu-ibu kelompok emping melinjo di Dusun Sengir Desa Kalirejo, Kecamatan Kokap, Kabupaten Kulon Progo. Program pelatihan inovasi olahan emping dengan metode in house training and workshop diselenggarakan oleh komunitas mahasiswa Pasca Sarjana Universitas Negeri Yogyakarta (UNY) yang bekerjasama dengan pihak kampus UNY yang bertujuan untuk melaksanakan program pengabdian kepada masyarakat Desa Kalirejo. Peneliti juga mengumpulkan informasi dari penyelenggara, pengelola dan fasilitator program tersebut untuk melengkapi data yang dibutuhkan.

Aspek-aspek yang digali yaitu pelaksanaan program pemberdayaan melalui in house training and workshop, Hasil program pemberdayaan ibu-ibu kelompok emping Desa Kalirejo dan faktor keberhasilan program pemberdayaan ibu-ibu kelompok emping Desa Kalirejo.

Subyek penelitian terdiri atas penyelenggara, fasilitator, dan warga belajar (ibu-ibu kelompok emping). Pemilihan subyek penelitian dilakukan dengan menggunakan teknik purposive sampling yang berjumlah 20 orang.

Data penelitian dikumpulkan melalui observasi (pengamatan), wawancara (interview) dan dokumentasi. Data dianalisis dengan teknik analisis kualitatif deskriptif seperti yang diungkapkan Miles, Huberman \& Saldana (Marshall et al., 2015) yaitu reduki data, penyajian data, dan penarikan kesimpulan. Untuk memeriksa keabsahan data, peneliti menggunakan triangulasi sumber.

\section{HASIL DAN PEMBAHASAN}

\section{Pelaksanaan Program In House Training and Workshop}

Kegiatan ini adalah sebuah program pelatihan yang bertujuan untuk mengolah emping agar lebih menarik dan inovatif, sehingga dapat meningkatkan ekonomi masyarakat ibu-ibu kelompok emping Desa Kalirejo.

Berdasarkan hasil penelitian dapat diketahui bahwa langkah-langkah pelaksanaan program pemberdayaan ibu-ibu kelompok emping dengan metode in house 


\section{Journal of Millennial Community, 2 (1), March 2020 - 12}

Khairun Nisa, Iis Prasetyo

training and workshop meliputi adanya perencanaan, pelaksanaan, evaluasi dan tindak lanjut. Persiapan/perencanaan meliputi identifikasi kebutuhan dan penetapan waktu dan tempat pelaksanaan, penentuan nara sumber dan materi pelatihan, penentuan jadwal kegiatan, dan penentuan evaluasi kegiatan.

Komponen-komponen

dalam

pelaksanaan program in house training and workshop meliputi: (1) nara sumber berasal dari pihak penyelenggara terdiri dari nara sumber pelatihan berasal dari pihak penyelenggara yaitu, narasumber inovasi pengolahan emping, narasumber pengemasan/packaging emping yaitu mahasiswa tata boga pascasarjana UNY yang sudah banyak mengikuti pelatihan tentang kuliner sampai ke laur negeri, narasumber pemasaran emping yang berasal dari perwakilan dari Dinas Koperasi UKM Kabupaten Kulon Progo dan Camat Kokap, (2) warga belajar, program program pelatihan inovasi olahan emping dengan metode in house training and workshop belajar ditujukan kepada ibu-ibu kelompok emping Dusun Sengir Desa Kalirejo. (3) untuk metode pembelajaran, narasumber menggunakan beberapa metode yaitu ceramah, praktik, dan diskusi. (4) Media Pembelajaran kegiatan pelatihan menggunakan in focus/ slide yang ditunjukkan kepada ibu-ibu. (5) materi pembelajaran kegiatan pelatihantermasuk dalam tingkat dasar yang harus diketahui pada masing-masing pelatihan. (6) strategi pembelajaran kegiatan pelatihan menggunakan strategi pendidikan orang dewasa dan konsep learning by doing. (7) proses pembelajaran, tahap-tahap proses pembelajaran yaitu persiapan, pemberian materi, kegiatan praktek, dan diskusi.

Monitoring dilakukan pada saat pelaksanaan setiap kegiatan pelatihan dan kegiatan evaluasi yang dilakukan adalah evaluasi praktik dan teori. Sedangkan tindak lanjutnya dilakukan melalui konsultasi dan pembinaan kepada warga belajar setelah program tersebut di laksanakan.

\section{Hasil Program In House Training and Workshop}

\section{a. Kondisi awal Peserta pelatihan}

Kondisi awal para peserta yang mengikuti pelatihan pembuatan emping ini adalah para ibu-ibu kelompok emping Desa Kalirejo belum mengetahui bagaimana cara mengolah emping agar menarik, ibu-ibu kelompok emping hanya menjual produk emping mereka dalam bentuk mentah dengan harga yang relative sangat murah, sehingga keuntungan yang didapat tidak terlalu tinggi. ibu-ibu kelompok emping juga belum tau bagaimana cara memasarkan empingnya agar bisa terjual laku di pasaran, serta belum tahu bagaimana cara mengawetkan emping melinjo agar empingnya tidak menghitam. Saat itu juga belum terdapat alat bantu yang dapat memudahkan para ibu-ibu dalam proses pembuatan emping tersebut.

\section{b. Hasil setelah pelatihan}

Hasil program pelatihan dan hasil yang dirasakan oleh ibu-ibu kelompok emping Desa Kalierjo setelah mengikuti kegiatan in house training and workshop adalah, (1) terciptanya produk hasil olahan emping, yaitu: keripik emping dengan berbagai rasa (balado, barbeque, jagung manis, coklat, pedas manis), dan cookies emping. Selain itu produk sudah diberi label semenarik mungkin serta pemasaran produk emping yang meningkat. (2) penambahan pengetahuan dan keterampilan pada ibu-ibu kelompok emping dalam membuat inovasi oalahan emping, pengemasan yang menarik dan strategi pemasaran, (3) penambahan relasi ibu-ibu kelompok emping, ditandai dengan memperoleh teman baru, baik dari pihak pascasarjana UNY dan Desa Kalirejo, (4) kegiatan usaha, ibu-ibu kelompok emping mulai memanfaatkan keterampilan baru yang sudah dimilikinya.

\section{Faktor Keberhasilan Program Pemberdayaan Melalui In House Training and Workshop}

Hasil penelitian menunjukkan bahwa pelaksaan program pelatihan inovasi olahan emping dengan metode in house training and workshop berjalan dengan lancar dan sesuai rencana. Hasil program menunjukkan bahwa 


\section{Journal of Millennial Community, 2 (1), March 2020 - 13}

Khairun Nisa, Iis Prasetyo

ibu-ibu kelompok emping sudah memanfaatkan keterampilan yang dimilikinya. Mereka sudah mulai memasarkan hasil inovasi produk emping ke pasaran dan pameran-pameran. Indikator yang ditentukan dalam menilai keberhasilan program yaitu dengan melihat peserta pelatihan sudah mampu mempraktikkan sendiri keterampilan yang diberikan dan mampu mengaplikasikannya dalam kehidupan.

Keberhasilan program ini tercapai karena adanya berbagai faktor yang mempengaruhinya. Faktor-faktor yang mempengaruhi keberhasilan program adalah: (1) adanya perencanaan program yang matang, (2) motivasi ibu-ibu kelompok emping untuk belajar sangat tinggi, (3) ketepatan materi dan metode pelatihan yang digunakan, (4) narasumber yang berkompeten, (5) penggunaan strategi pelatihan dengan in house training and workshop yang tepat, (6) sarana dan prasarana yang memadai.

\section{Pembahasan}

Pemberdayaan atau empowerment berarti proses pemberian daya atau kekuatan kepada individu/kelompok. Saugi dan Sumarno (2015) menyatakan pemberdayaan masyarakat pada dasarnya merupakan strategi perubahan sosial secara terencana yang ditujukan untuk mengatasi masalah atau memenuhi kebutuhan masyarakat. Pernyataan tersebut sesuai dengan pendapat Miradj dan Sumarno (dalam Ningrum \& Sujarwo, 2017) menekankan pemberdayaan sebuah upaya untuk memberikan kekuatan atau daya untuk masyarakat dengan memanfaatkan kemampuan dan potensi yang dimiliki oleh masyarakat. Kasmel dan Anderson ( dalam Ningrum \& Sujarwo, 2017) menyatakan bahwa community empowerment is understood either as a process or as an outcome. Pemberdayaan dimaknai sebagai proses atau sebagai hasil.

Program in house training and workshop yang difokuskan pada inovasi dan pemasaran produk emping adalah salah satu upaya pemberdayaan yang berusaha memberikan pengetahuan dan keterampilan ibu-ibu kelompok emping Desa Kalirejo.
Bentuk kegiatan program tersebut adalah pelatihan menciptakan inovasi olahan pangan berbahan dasar emping dan pemasaran.

Program pelatihan dimulai dengan penyampaian tentang izin usaha dan bagaimana prosedur dalam perizinan. narasumber menyampaikan secara lengkap tentang pembuatan izin untuk usaha yang akan didirikan. Tujuan izin ini dibuat agar produk tersebut memenuhi standar penjualan sehingga produk dapat bersaing di tokoh perkotaan maupun tokoh oleh-oleh. Harus adanya motivasi untuk tetap berusaha dalam mendirikan suatu usaha serta tidak menyerah jika terjadi suatu kegagalan tetapi, terus berusaha mempelajari agar tidak terjadi kesalahan yang sama. Pembuatan laporan keuangan juga menjadi salah satu faktor keberhasilan dalam mendirikan usaha dimana, laporan keuangan harus secara rapi disusun termasuk modal, pemasukan, pengeluaran dan keuntungan. Laporan keuangan yang rapi akan dapat membantu megelolah keuangan untuk memutar balik keuntungan yang sudah didapat. Sehingga ditengah jalan tiba-tiba terjadi penurunan produksi usaha tersebut dapat terus bertahan dan tidak gulung tikar. Setelah itu, dilanjutkan diskusi dengan para peserta. Setelah itu dilanjutkan dengan praktik pengolahan inovasi emping menjadi keripik emping dengan berbagai rasa dan cookies emping serta terakhir melakukan pengemasan.

Berdasarkan penjelasan kegiatan di atas, dapat dijelaskan bahwa yang menjadi tujuan dari program pelatihan in house training and workshop dengan mengembangkan produksi emping adalah: (1) untuk memberikan pengetahuan dan keterampilan bagi komunitas ibu-ibu kelompok emping sesuai kebutuhan mereka, (2) memanfaatkan Balai Desa untuk kegiatan-kegiatan yang bermanfaat, (3) memotivasi ibu-ibu kelompok emping agar terus meningkatkan pengetahuan dan keterampilan yang mereka miliki.

Perumusan tujuan merupakan salah satu komponen penting dalam penyelenggaraan suatu program maupun pelatihan. Menurut Kamil (dalam Ningrum 
\& Sujarwo, 2017)tujuan yang dirumuskan akan menuntun penyelenggaraan program maupun pelatihan dari awal sampai akhir kegiatan, dari pembuatan rencana pembelajaran hingga evaluasi hasil belajar. Perumusan tujuan harus dirumuskan lebih spesifik, kongkret, dan jelas tentang apa yang harus dicapai dengan penyelenggaraan program maupun pelatihan tersebut. Dengan demikian, perumusan tujuan program pelatihan in house training and workshop tersebut harus lebih kongkret dan jelas terkait dengan kompetensi atau keterampilan yang ingin dicapai dalam penyelenggaraan program pelatihan tersebut. Perumusan tujuan demikian akan lebih mudah memandu penyelenggara untuk merencanakan proses pembelajaran, materi, media hingga evaluasi hasil belajar.

Program in house training and workshop tersebut berupa penyelenggaraan pelatiha olahan inovasi emping dan pemasaran. Training is a performance development process to foster learning new techniques and methods to perform job with fullest efficiency and effectiveness. Successful training and development program assist the strategic requirement of the organization and also satisfies the individual needs of the people working in it. (Karim et al., 2012) Pelatihan tersebut diharapkan mampu memberikan pengetahuan dan keterampilan yang akan mewujudkan warga belajar menjadi mandiri. Hal ini sesuai dengan konsep pemberdayaan yang diungkapkan oleh Sulistiyani (dalam Pamuji, 2017) bahwapemberdayaan bertujuan untuk membentuk individu dan masyarakat menjadi mandiri.

Suparjan dan Suyatno (dalam Ningrum \& Sujarwo, 2017) menekankan bahwa pemberdayaan tidak dapat serta terwujud dengan cepat, perlu adanya beberapa tahap yang harus dilalui, dimulai dari penyadaran masyarakat terkait posisimya dalam sosial dan politik, peningkatan kapasitas hingga pemberdayaan tersebut terwujud. Berdasarkan hasil penelitian, program in house training and workshop ini memiliki berbagai tahap yang meliputi persiapan, pelaksanaan, monitoring dan evaluasi, serta tindak lanjut program. Tahap persiapan terdapat kegiatan perekrutan warga belajar. Penyelenggara memberikan sosialisasi program kepada sasaran program terkait dengan pelaksanaan program dan latar belakang diadakannya program dan kegiatan yang ditawarkan dalam program tersebut. Warga belajar (ibu-ibu kelompok emping) bersedia mengikuti kegiatan pelatihan dengan sukarela. Harapannya, warga belajar yang mengikuti kegiatan dalam program tersebut adalah warga belajar yang memiliki motivasi yang tinggi untuk belajar.

Penjaringan warga belajar menjadi kunci yang dapat menentukan keberhasilan langkah selanjutnya. Kamil (Ningrum \& Sujarwo, 2017) menjelaskan bahwa dalam rekruitmen atau penjaringan warga belajar ini penyelenggara diharapkan menetapkan beberapa persyaratan yang harus dipenuhi oleh peserta terutama yang berhubungan dengan karakteristik peserta yang bisa mengikuti pelatihan. Berdasarkan penjelasan tersebut dapat diketahui bahwa penyelenggara program maupun pelatihan perlu membuat kriteria atau persyaratan warga belajar yang mengikuti program maupun pelatihan yang akan dilaksanakan. Penyelenggara program in house training and workshop belum merumuskan kriteria atau persyaratan warga belajar yang dapat mengikuti program tersebut. Semua calon warga belajar dapat mendaftar secara langsung dan diterima menjadi warga belajar.

Pada tahap pelaksanaan program, penyelenggara mengadakan dua kegiatan pelatihan berupa pelatihan mengolah emping dan pelatihan mengemas/packaging emping. Pelaksanaan pada masing-masing kegiatan tersebut memberikan pengetahuan dan ketrampilan kepada warga belajar. Dengan demikian, adanya proses transformasi yaitu narasumber memberikan pengetahuan dan ketrampilan kepada warga belajar dan warga belajar menerima pengetahuan dan ketrampilan tersebut. Hal ini sesuai dengan pendapat Sulistyani (dalam Pamuji, 2017) bahwa dalam pemberdayaan terdapat tahap transformasi. Proses pembelajaran dilakukan dengan 3 metode pembelajaran, yaitu: ceramah, praktek, dan diskusi. 


\section{Journal of Millennial Community, 2 (1), March 2020 - 15}

Khairun Nisa, Iis Prasetyo

Berdasarkan hasil wawancara diketahui bahwa metode-metode pelatihan yang digunakan sudah tepat dan sesuai dengan materi yang diberikan berupa teori dan praktik. Materi yang diberikan mudah dipelajari karena proporsi materi lebih banyak praktek dibandingkan teori yang memiliki presentase 75\%:25\%. Warga belajar dapat mempraktekkan materi yang didapatkan secara langsung, Hal tersebut sejalan dengan konsep learning by doing, yaitu belajar dengan melakukannya. Warga belajar memahami segala sesuatu dengan melakukannya. Strategi pembelajaran learning by doing sangat sesuai digunakan dalam program pemberdayaan khusunya pada kegiatan pelatihan. Warga belajar yang tergolong orang dewasa juga akan merasa lebih paham apabila mempraktekkan materi yang disampaikan.

Strategi pembelajaran yang digunakan narasumber sudah sesuai dengan kebutuhan warga belajar. Sarana dan prasarana terkait dengan peralatan dan bahan yang digunakan dalam kegiatan pelatihan juga sudah memenuhi kebutuhan peserta pelatihan. Namun, dalam proses pembelajaran perlu diperhatikan terkait dengan perbandingan jumlah peserta pelatihan dengan narasumber. Jumlah narasumber dalam masing-masing kegiatan pelatihan hanya berjumlah 1 orang dan jumlah warga belajar sekitar 15-20 orang. Menurut Kementrian Kesehatan RI (Ningrum \& Sujarwo, 2017) perbandingan jumlah ideal fasilitator dalam menangani peserta program pelatihan adalah 1:6. Berdasarkan penjelasan tersebut, dapat diketahui bahwa perbandingan jumlah narasumber dan dan warga belajar sebaiknya 1:6.

Perbandingan jumlah warga belajar dan narasumber perlu diperhatikan agar materi yang diberikan mudah untuk dipahami oleh warga belajar. Dengan demikian, narasumber yang dibutuhkan dalam masing-masing pelatihan ini perlu disesuaikan dengan jumlah warga belajar yang diampu. Jumlah narasumber program in house training and workshop dibantu oleh 2-3 orang pemandu untuk membantu narasumber dalam memandu warga belajar khususnya pada kegiatan praktek. Pemandu harus disesuaikan dengan kompetensi yang dibutuhkan pada masing-masing kegiatan pelatihan.

Tahap terakhir menurut teori yang akan terjadi pada proses pemberdayaan adalah tahap peningkatan kemampuan intelektual, kecakapan-keterampilan sehingga terbentuklah inisiatif dan kemampuan inovatif untuk mengantarkan pada kemandirian. Tahap tersebut terjadi ketika peserta pelatihan sudah merasakan manfaat secara langsung terhadap pengetahuan dan keterampilan yang sudah dikuasai. Warga belajar mampu memanfaatkan kemampuan yang dimiliki untuk kegiatan usaha. Dengan demikian, hasil program yang dirasakan langsung oleh warga belajar adalah memotivasi warga belajar untuk menggunakan keterampilan yang dimiliki untuk kegiatan usaha.

Peserta pelatihan mencoba untuk merintis usaha dengan menggunakan keterampilan baru yang mereka miliki. Hal ini sesuai dengan tahap dalam proses pemberdayaan yaitu adanya inisiatif dan kemampuan inovatif untuk mengantarkan pada kemandirian, peserta pelatihan juga memiliki inisiatif untuk melakukan kegiatan usaha dengan memanfaatkan kemampuan yang sudah dimiliki setelah mengikuti kegiatan pelatihan ini. Kegiatan usaha ini mampu membuat warga belajar mandiri dalam memenuhi kebutuhannya, artinya warga belajar memiliki tambahan pendapatan untuk memenuhi kebutuhannya secara mandiri.

Berdasarkan penjelasan tersebut maka dapat diketahui bahwa tahap-tahap yang dilalui dalam pelaksanaan hingga hasil program pelatihan inovasi olahan emping dengan metode in house training and workshop sejalan dengan tahap-tahap proses pemberdayaan. Program in house training and workshop adalah suatu upaya dalam pemberdayaan bagi suatu komunitas tertentu. Komunitas yang dimaksud adalah ibu-ibu kelompok emping Desa Kalirejo Kecamatan Kokap, Kabupaten Kulon Progo yang mengikuti kegiatan ini.

Komunitas ibu-ibu kelompok emping Desa Kalirejo diharapkan mampu menjadi komunitas belajar atau learning community. 
Menurut Boshier dalam Shofwan (dalam Ningrum \& Sujarwo, 2017) menyatakan learning community is the nation of learning society stems from third force psychology, widespread disenchantment with traditional education, the writing of educational radicals such as Illich, Reimer, Goodman, and Freire, and the unprecedented transformation wrought by economic and social changes associated with evolving technology. Komunitas belajar atau learning community dipandang sebagai pendidikan alternatif yang memberikan pelayanan pendidikan di luar persekolahan.

Berdasarkan penelitian yang sudah dilakukan, diketahui bahwa peserta pelatihan sudah memiliki pengetahuan dan keterampilan sesuai dengan pelatihan yang diikuti namun belum semua peserta pelatihan memiliki motivasi untuk terus belajar. Penyelenggara harus terus memotivasi warga belajar untuk terus meningkatkan kemampuan yang dimilikinya. Penyelenggara dapat melakukan hal tersebut melalui kegiatan monitoring dan evaluasi pada kegiatan tindak lanjut program. Kegiatan monitoring dan evaluasi tidak hanya dilaksanakan dalam proses pembelajaran. Kegiatan monitoring dan evaluasi diharapkan dilaksanakan pada pra pelaksanaan, pelaksanaan, dan pasca pelaksanaan program.

Evaluasi program merupakan kegiatan untuk menilai seluruh kegiatan pelatihan dari awal sampai akhir, dan hasilnya menjadi masukan bagi pengembangan pelatihan selanjutnya (dalam Ningrum \& Sujarwo, 2017). Evaluasi program dilaksanakan dari awal hingga akhir dan hasil evaluasi dapat dijadikan sebagai bahan pertimbangan dalam mengambil keputusan. Penyelenggara mampu mengidentifikasi faktor pendukung dan penghambat program mulai dari awal hingga akhir penyelengaraan program. Kegiatan evaluasi yang dilaksanakan oleh penyelenggara program pelatihan inovasi olahan emping dengan metode in house training and workshop masih pada evaluasi pembelajaran dan belum pada kegiatan evaluasi program. Penyelenggara perlu mengadakan kegiatan evaluasi awal dan setelah program dilaksanakan.
Tahap-tahap pada pelaksanaan program pelatihan inovasi olahan emping dengan metode in house training and workshop sudah sejalan dengan tahap pemberdayaan. Namun, masih terdapat halhal yang perlu diperbaiki dalam pelaksanaan program pelatihan ini. Perbaikan tersebut diperlukan dalam kegiatan perumusan tujuan, penjaringan kerjasama denga pihak desa, pemenuhan jumlah narasumber, serta kegiatan monitoring dan evaluasi program pelatihan. Perbaikan dalam pelaksanaan program pelatihan in house training and workshop tersebut diharapkan mampu mewujudkan pemberdayaan ibu-ibu kelompok emping yang lebih baik.

Hasil yang dicapai dalam pemberdayaan yaitu adanya peningkatan kemampuan berupa pengetahuan dan ketrampilan yang nantinya mampu mencapai perubahan sosial. Pemberdayaan merupakan usaha untuk mengalihkan "daya" kepada sasaran program yang harapannya sasaran program akan berdaya. Berdasarkan hasil penelitian diketahui bahwa salah satu perubahan pada warga belajar setelah mengikuti program ini yaitu adanya penambahan pengetahuan dan keterampilan. Ibu-ibu kelompok emping memiliki keterampilan dalam bidang pengolahan emping, pengemasan dan pemasaran. Perubahan tersebut terlihat ketika warga belajar mampu mempraktekkan semua materi yang diberikan oleh narasumber.

Hasil penelitian menunjukkan bahwa antusias warga belajar untuk terus belajar tinggi. Antusiasme tersebut muncul dikarenakan adanya ketertarikan warga belajar terhadap materi yang disampaikan dan adanya keinginan untuk terus meningkatkan pengetahuan dan ketrampilan yang dimiliki. Dengan demikian, dapat diketahui bahwa kesadaran untuk belajar sudah tumbuh dalam diri warga belajar. Dengan demikian, diketahui bahwa program in house training and workshop menyediakan kegiatan pelatihan sesuai dengan potensi dan kebutuhan masyarakat.

Berdasarkan pembahasan terkait dengan hasil program dapat disimpulkan bahwa hasil program pada Pondok 
Komunitas Belajar mengacu pada indikator pemberdayaan yang diperoleh dari berbagai kajian teori yang relevan. Hasil program pada program Pondok Komunitas yang merupakan suatu upaya pemberdayaan masyarakat ini meliputi: penambahan pengetahuan dan ketrampilan, adanya motivasi untuk meningkatkan pengetahuan dan ketrampilan, penambahan relasi, dan adanya kegiatan usaha.

Keberhasilan program tercapai apabila hasil dari program sesuai dengan indikatorindikator yang sudah direncanakan sebelumnya. Program pelatihan in house training and workshop adalah salah satu program desa binaan yang diselenggarakan oleh pihak pascasarajana UNY. Keberhasilan suatu program adalah dinilai dari kebermanfaatan program bagi masyarakat karena salah satu tugas dari pemberdayaan masyarakat yaitu mampu melayani kebutuhan masyarakat. Hal ini sesuai dengan kajian teori yang menjelaskan bahwa Community Learning Center dibentuk untuk membuat program baru yang sesuai dengan kebutuhan masyarakat. Community Learning Center dapat melakukan program apapun asalkan melayani kebutuhan masyarakat. Seperti halnya program ini sebagai salah satu unit pelaksana pendidikan non-formal membuka berbagai pelayanan pendidikan non-formal baik yang disesuaikan dengan program pemerintah maupun program yang dikembangkan sesuai dengan kebutuhan masyarakat.

Berdasarkan hasil penelitian, dapat diketahui bahwa program pelatihan ini sudah mampu mengelola program pendidikan nonformal yang menggunakan sumber belajar secara efisien. Program Pondok Komunitas Belajar yang diselenggarakan mampu memenuhi kebutuhan sasaran program dan menggunakan sumber belajar dengan tepat. Hal ini dibuktikan dengan warga belajar mudah memahami materi yang diberikan dalam kegiatan pelatihan yang diselenggarakan pada program ini.

Warga belajar mampu memahami dan menggunakan sumber belajar yang disediakan oleh penyelenggara program.
Selain sumber belajar, narasumber mengunakan metode dan strategi pelatihan yang tepat bagi warga belajar. Metode dan strategi pelatihan yang digunakan mampu memberikan kemudahan bagi warga belajar dalam mempelajari materi yang diberikan. Komposisi pembelajaran dengan memperbanyak praktek dibandingkan teori membuat warga belajar dapat langsung mempraktekkan materi yang disampaikan. Hal ini sesuai dengan konsep pembelajaran learning by doing, yaitu belajar sambil melakukannya. Strategi pembelajaran sangat tepat bagi orang dewasa yang harapannya warga belajar lebih mudah untuk mengaplikasikan ketrampilan tersebut.

Keberhasilan program ini tercapai karena adanya berbagai faktor yang mempengaruhinya. Dari penjelasan di atas maka dapat diketahui bahwa program in house training and workshop sudah mampu berperan sebagai Community Learning Center yaitu sebagai tempat yang menghubungkan ketiga lingkungan belajar di masyarakat yaitu sekolah, keluarga, dan masyarakat dan menyelenggarakan berbagai program pendidikan non formal yang disesuaikan dengan kebutuhan masyarakat.

Berdasarkan hasil penelitian, peneliti menyimpulkan bahwa faktor-faktor yang mempengaruhi keberhasilan program pemberdayaan in house training and workshop adalah: adanya perencanaan program yang matang, motivasi belajar warga belajar tinggi, ketepatan materi dan metode pembelajaran, narasumber yang berkompeten dan penggunaan strategi pelatihan yang tepat, serta sarana dan prasarana yang memadai. Keberhasilan program tidak hanya dipengaruhi oleh penyelenggara program namun juga respon dari warga belajar dalam mengikuti program tersebut. Hal ini berhubungan dengan peran penyelenggara, narasumber dan warga belajar yang saling berinteraksi secara bersama-sama untuk mencapai tujuan bersama. Penyelenggara mampu merancang perencanaan program, narasumber berperan dalam memilih dan menggunakan materi, media, metode dan strategi pembelajaran yang tepat. Sedangkan warga belajar memiliki motivasi belajar yang tinggi. Ketiga 
peran tersebut merupakan tiga faktor utama yang mempengaruhi keberhasilan program in house training and workshop yang diselenggarakan oleh komunitas keluarga mahasiswa pascasarjana UNY. Namun,

dalam keberhasilan program tersebut masih terdapat beberapa kekurangan dalam pelaksanaan program yang perlu diperbaiki

\section{SIMPULAN}

Hasil pemberdayaan berkaitan dengan perubahan pengetahuan, ketrampilan, sikap, dan kemandirian individu maupun kelompok di masyarakat. Hasil penyelenggaraan pemberdayaan ibu-ibu kelompok emping Desa Kalirejo, Kecamatan Kokap Kabupaten Kulon Progo meliputi: (a) penambahan pengetahuan dan keterampilan terkait dengan mengolah, mengemas dan memasarkan hasil produk inovasi olahan emping, (b) adanya motivasi untuk menambah pengetahuan dan keterampilan yang sudah dimiliki, hal ini ditandai adanya warga belajar yang ingin melanjutkan pelatihan ke jenjang lebih tinggi. (c) penambahan relasi, warga belajar memperoleh teman baru baik dari temanteman pelatihan maupun dari pihak KMP UNY. dan (d) kegiatan usaha, peserta pelatihan mulai memanfaatkan keterampilan baru yang sudah dimilikinya.

\section{DAFTAR PUSTAKA}

Ayuningtyas, A. E., Slameto, S., \& Dwikurnaningsih, Y. (2017). Evaluasi Program Pelatihan In House Training (IHT) di Sekolah Dasar Swasta. Kelola: Jurnal Manajemen Pendidikan, 4(2), 171183.

https://doi.org/https://doi.org/10.24246 /j.jk.2017.v4.i2.p171-183

Karim, M. R., Huda, K. N., \& Khan, R. S. (2012). Significance of training and post training evaluation for employee effectiveness: An empirical study on Sainsbury's Supermarket Ltd, UK. International Journal of Business and Management, 7(18), 141. Retrieved from https://pdfs.semanticscholar.org/ebda/ 6915723382539b241affbc8881f4cab9d4e3. pdf dan diperhatikan oleh penyelenggara. Dengan demikian, penyelenggara perlu memperbaikii kekurangan pada pelaksanaan pemberdayaan pedagang pasar tradisional dalam pondok komunitas belajar ini, sehingga pelaksanaan program pelatihan pada periode selanjutnya lebih baik.

Kasryno, F., Gunawan, M., \& Rasahan, C. A. (1993). Strategi Diversifikasi Produksi Pangan. Prisma, (5).

Mandayani, S., \& Hasibuan, J. Pemberdayaan Ibu Rumah Tangga Dalam Pemanfaatan Pekarangan Pasar Melalui Kelompok Wanita Tani (KWT) Sanggar Rezeki. Journal of Millennial Community, 1(1), 27-30.

Mardikanto, T. (2014). CSR (Corporate Social Responsibility)(Tanggungjawab Sosial Korporasi). Bandung: Alfabeta.

Marshall, C., Brereton, P., \& Kitchenham, B. (2015). Tools to support systematic reviews in software engineering: a cross-domain survey using semistructured interviews. In Proceedings of the 19th international conference on evaluation and assessment in software engineering (pp. 1-6). Retrieved from https://dl.acm.org/doi/abs/10.1145/2745 802.2745827

Ningrum, M. D., \& Sujarwo, S. (2017). Pemberdayaan pedagang pasar tradisional dalam pondok komunitas belajar di sanggar kegiatan belajar Kabupaten Wonogiri. JPPM (Jurnal Pendidikan dan Pemberdayaan Masyarakat), 4(2), 199-214. Retrieved from http://staffnew.uny.ac.id/upload/132304 795/penelitian/Pemberdayaan.

Nofriyanto, R., Rahmidani, R., \& Cerya, E. (2019). Pengaruh Iklan Televisi Dan Desain Kemasan Terhadap Keputusan Pembelian Sabun Pembersih Wajah Biore pada Mahasiswa Universitas Negeri Padang. Jurnal Ecogen, 1(4), 905- 
Journal of Millennial Community, 2 (1), March 2020 - 19

Khairun Nisa, Iis Prasetyo

914. Retrieved from

http://103.216.87.80/students/index.php /pek/article/view/567o

Pamuji, I. A. (2017). Pemberdayaan Perempuan Indonesia Maju Mandiri di Desa Rantau Layung Kecamatan Batu Sopang Kabupaten Paser. Jurnal Universitas Mulawarman, 1(1), 1-15. Retrieved from http://perpustakaan.unmul.ac.id/ejour nal/index.php/um/article/view/11

Sagita, L., \& Sari, M. W. (2019). Pelatihan Pembuatan Desain dan Label Produk Lurik-Kulit di Panggungharjo Bantul. Abdimas Dewantara, 2(2), 115-119. https://doi.org/10.30738/ad.v2i2.2762

Saugi, W., \& Sumarno, S. (2015). Pemberdayaan perempuan melalui pelatihan pengolahan bahan pangan lokal. JPPM (Jurnal Pendidikan dan Pemberdayaan Masyarakat), 2(2), 226238.

\section{PROFIL SINGKAT}

Penulis 1

Khairun Nisa adalah mahasiswa kelahiran tahun 1995, berasal dari Desa Labuhanbilik, Kecamatan Panai Tengah, Kabupaten Labuhan Batu, Sumatera Utara, Lulusan S1 Pendidikan Luar Sekolah (PLS) di Universitas Negeri Medan (UNIMED) tahun 2017, dan sekarang sedang menempuh pendidikan S2 di Universitas Negeri Yogyakarta (UNY) dengan jurusan Pendidikan Non Formal.

Penulis 2

Iis Prasetyo, adalah dosen Universitas Negeri Yogyakarta, dengan riwayat pendidikan S1 Pendidikan Luar Sekolah di Universitas Negeri Yogyakarta (UNY) tahun 2003, S2 Manajemen Pendidikan di Universitas Gadjah Mada (UGM) tahun 2007, S3 Pendidikan Luar Sekolah di Universitas Pendidikan Indonesia (UPI) tahun2011. 